ISSN 2078-6441. Вісник Львівського університету. Серія географічна. 2014. Випуск 47. С. 177-184. Visnyk of the Lviv University. Series Geography. 2014. Issue 47. P. 177-184.

910.26:911.52

\author{
лекс ндр кртчян \\ ьвівський н ціон льний університет імені в н \\ вул. . орошенк , 41, 79000, м. ьвів, кр їн, \\ e-mail: alemkrt@gmail.com
}

озглянуто принципи втом тизов ного л ндш фтно-екологічного $\mathrm{p}$ йонув ння території метод ми кл стериз ції т сегмент ції. бгрунтов но використ ння еколого-морфометричних індексів як критеріїв л ндш фтно-екологічної кл стериз ції т сегмент ції. пропонов но методику кількісного н лізу просторової пов'яз ності типологічних т регіон льних одиниць н підст ві теорії інформ ції.

лючові слов : р йонув ння, кл стериз ція, сегмент ція.

и не н йв жливіший метод геогр фії - p йонув ння - поляг є в поділі певної ч стини земної поверхні н змістовно бо функціон льно однорідні ч стини. ункціон льно однорідні ч стини інтерпретують у світлі теоретичних концепцій конкретної геогр фічної н уки, зокрем, як системні єдності, ч стини систем бо ре ли прояву певних процесів бо явищ.

озвиток геоінформ ційних технологій відкрив можливості втом тиз ції цього методу, коли виділення територі льних одиниць відбув ється з допомогою відповідного лгоритму н підст ві н перед з д них критеріїв т пок зників. цьому р зі треб розрізняти н пів втом тизов не р йонув ння н з с д х н перед визн чених кл сифік ційних озн к т втом тизов не, з якого кл сифік ційні озн ки визн ч ють у ході кл сифік ції н підст ві н лізу структури д них. ерев г ми втом тизов ного виділення територі льних одиниць є відтворюв ність, об'єктивність, швидкість, можливість виявлення прихов них структур у д них. оч геоінформ ційні технології широко з стосовують у геогр фічних дослідженнях уже впродовж двох десятиліть, пит ння втом тизов ного р йонув ння розроблені й вивчені недост тньо.

геогр фії є дв підходи до р йонув ння: типологічний і регіон льний. ерший поляг є у виділенні ре лів н перед визн чених типів (місцеположень, рослинності, клім ту, грунтів тощо), другий - у поділі території н ч стини, які вв ж ють однорідними $з$ певним комплексом озн к (біогеоценози, форми рельєфу, л ндш фти тощо).

етод р йонув ння в геогр фії є певною мірою н логом методу кл сифік ції, який з стосовують у різних природничих н ук х. утність методу кл сифік ції поляг $є$ у групув нні об'єктів дослідження чи спостережень відповідно до їхніх з г льних озн к. роте в геогр фії, н відміну від 6 г тьох природничих н ук, є проблем вибору т ідентифік ції елемент рного об'єкт дослідження. скільки х р ктерн специфік геогр фії - дослідження геопросторових (територі льних) відношень т структур, то ії елемент рний об'єкт м є бути включений у т кі відношення, одноч сно він повинен

(C) кртчян ., 2014 
м ти внутрішню геопросторову неподільність т однорідність (в ін кшому вип дку цей об'єкт може бути поділеним н дрібніші скл дові і вже не буде елемент рним).

ким елемент рним об'єктом геогр фії може слугув ти місцеположення ( нгл. site), що відповід є будь-яким ділянк м земної поверхні, які розгляд ють (у меж х певного н укового дослідження бо прикл дної проблем тики) як т кі, що м ють (умовно) внутрішню просторову однорідність (гомогенність). імецькі дослідники розробили концепцію “топів” - н йменших просторових одиниць, яким вл стив гомогенність змісту т одном нітність процесів, пов'яз них з певним геокомпонентом (морфотоп, педотоп, клім топ, гідротоп) бо з усім геокомпонент ми, що зумовлює екологічну гомогенність т ких одиниць (екотоп, геотоп). скільки ж поняття гомогенності з вжди $є$ відносним, то нем є підст в для того, щоб у р зі виділення т ких одиниць обмежув тись певним просторовим м сшт бом. прикл д, під екотопом можн розуміти ділянку, ступінь екологічної гомогенності якої є дост тнім для вирішення конкретного н укового чи пр ктичного з вд ння, тому т ку ділянку недоцільно поділяти н дрібніші скл дові з цим критерієм. кі топічні одиниці можуть скл д тися з відмінних елементів, які утворюють регулярну моз їку (н прикл д, грунтові комплекси). кл д і співвідношення т ких елементів для кожного комплексу можн з зн ч ти в легенді к рти, проте ці елементи окремо не к ртують, тобто внутрішня геопросторов неоднорідність т структур топічних одиниць є поз інтересом т сферою ув ги дослідник .

ельєф земної поверхні - в жливий чинник перерозподілу сонячної р ді ції, вологи т потоків речовини н земній поверхні. и 3 пропонув ли виділення н укового н пряму - екологічної морфометрії як г лузі екологічної геоморфології, як досліджує екологічне зн чення морфометричних $\mathrm{x}$ р ктеристик рельєфу, з лежності між морфометричними п р метр ми т екологічними чинник ми [3]. дним із з вд нь екологічної морфометрії є екологічн регіон ліз ція території вн слідок її поділу н морфотопи - територі льні одиниці, які виділяють 3 озн к ми морфології земної поверхні, виходячи з принципу екологічної однорідності [5].

типологічного підходу до р йонув ння геопросторовий спект не беруть до ув ги, критеріями р йонув ння слугують речовинно-енергетичні х р ктеристики (н прикл д, х р ктеристики водного режиму території, режиму н дходження сонячної енергії, особливості мігр ції мінер льних речовин у л ндш фті). ідповідно, у підсумку отримуємо територі льні одиниці, що є просторово розімкнутими (предст вленими сукупністю геометрично не пов'яз них між собою виділів). томість, 3 регіон льного підходу серед критеріїв р йонув ння є геопросторові х р ктеристики (суміжність, комп ктність тощо). підсумку отримуємо просторово суцільні територі льні одиниці.

етодик втом тизов ного виділення територі льних одиниць відрізняється від того, який с ме підхід - типологічний чи регіон льний - беруть 3 основу р йонув ння.

першому вип дку метод р йонув ння принципово не відрізняється від звич йної кл сифік ції б г товимірних д них. окрем, методик ітер ційного кл стерного н лізу д є змогу виділити кл си н підст ві н лізу природних поєдн нь д них (кл стерів) у просторі трибутів (кл стериз ція методом k-середніх). лгоритм, н якому грунтується ця методик, поляг є в розміщенні у просторі трибутів (пок зників, які використовують у кл сифік ції) $\mathrm{k}$ центроїдів ( $\mathrm{k}$ відповід $є 3$ д ній кількості кл стерів) т віднесенні кожного елемент (місцеположення, піксели) до кл стер із н йближчим до нього положенням центроїд в б г товимірному просторі трибутів 3 н ступним перер хунком положення центроїдів усіх кл стерів. ісля певної кількості ітер цій 
отримуємо поділ простору трибутів н $\mathrm{k}$ обл стей, кожній з яких відповід $є$ розміщений в ній окремий кл стер (сукупність елементів з подібними зн ченнями трибутів).

я методик д є змогу з д в ти довільну кількість кл стерів, н які поділяють елементи (місцеположення). ільш кількість кл стерів відповід є більшій дет льності кл сифік ції т вищому ступеню однорідності отрим них кл стерів. скільки оптим льн кількість кл стерів, як відповід є об'єктивній структурі д них, н перед невідом , то можн послідовно виконув ти кл сифік цію з різною кількістю кл стерів, порівнюючи отрим ні результ ти й обир ючи в рі нт, який н йліпше підд ється змістовній інтерпрет ції.

p зі регіон льного підходу до р йонув ння певним н логом цього методу $\epsilon$ метод сегмент ції. його основі - процедур, подібн до методики виділення вододілів з цифровою моделлю рельєфу ( ). поч тку визн ч ють в рі бельність зн чення $\mathrm{x}$ р ктеристики чи сукупності $\mathrm{x}$ р ктеристик в околицях конкретного місцеположення, обчислюючи дисперсію в меж х ковзного вікн н перед визн чених розмірів. лі обчислені зн чення в рі бельності використовують як н лог зн чень висот . омогенні ділянки в цьому $\mathrm{p}$ зі відповід ють “з п дин м", ділянки підвищеної гетерогенності - “височин м” і “хребт м”, які їх розділяють. лі відповідний лгоритм виділяє н цій поверхні уявні "річкові б сейни”, які м ють високий рівень внутрішньої гомогенності з критеріями сегмент ції порівняно з відмінностями цих критеріїв між т кими “б сейн ми”. н ступному ет пі “б сейни”, що є просторово суміжними (м ють спільну межу), об'єднують у більші сегменти з озн кою подібності критеріїв сегмент ції. ей процес $є$ ітер тивним. кожному кроці ітер ції кожний сегмент порівнюють з усім суміжними сегмент ми й об'єднують 3 тим, що н йбільше подібний до нього. цьому вип дку в рі бельність критеріїв між сегмент ми, які є к ндид т ми н об'єдн ння, порівнюють з п р метром допуску, який з д ють довільно перед з пуском лгоритму сегмент ції. ише ті сегменти можуть бути об'єдн ні в один більший сегмент, відмінності між якими не перевищують зн чення п р метр допуску. ідповідно, чим більше зн чення цього п р метр ми з д ємо, тим д лі просув ється процедур сегмент ції і тим меншу кількість сегментів отримуємо н виході. тже, цей п р метр певною мірою н логічний п р метру кількості кл стерів, яку з д ють під ч с процедури втом тизов ної кл стериз ції.

ериторія н шого дослідження - це прямокутн ділянк розмір ми 90×70 км, розміщен в центр льній ч стині кр їнських рп т. і гон ль прямокутник приблизно відповід є осі к рп тської дуги: отже, ділянк охоплює північний і південний м кросхили рп т т (північний схід ділянки) ч стину ередк рп ття (див. рис. 1). ке розт шув ння ділянки д ло змогу включити до неї низку різном нітних з л ндш фтного погляду структурно-тектонічних зон. прикл д, ділянк досліджень охоплює т кі фізико-геогр фічні обл сті: ередк рп тську височинну, овнішньок рп тську, ододільноверховинську, олонинсько- орногірську т улк нічно-міжгірно-улоговинну [2].

жерелом геопросторових д них слугув л SRTM v. 4.1, отрим н 3 онл йнового рхіву онсорціуму просторової інформ ції CGIAR (http://srtm.csi.cgiar.org). ихідні д ні - у геогр фічній координ тній системі (еліпсоїд WGS84) з просторовою роздільністю близько 90 м; для спрощення н лізу д них їх спроектов но в координ тну систему UTM (зон 34N). к критерії кл сифік ції використ но комплексні пок зники (індекси), які безпосередньо х р ктеризують рельєф з екологічного погляду. окрем, для відобр ження перерозподілу вологи 3 елемент ми рельєфу під дією 
гр віт ції використ но з пропонов ний . уром т . есслером топогр фічний індекс вологості, який відтворює положення в л ндш фтній к тені т який обчислюють 3 формулою $C T I=\ln \left(A_{s} / \tan \beta\right)$, де $A_{s}-$ дрен жн площ (площ водозбору, розр хов н н одиницю довжини з мик льного контуру); $\beta$ - похил поверхні [8]. ля визн чення ерозійного потенці лу рельєфу з стосов но вир з із модифіков ного універс льного рівняння втр т грунту (RUSLE):

$$
L S=(m+1)\left[A_{s} / a_{0}\right]^{m}\left[\sin \beta / b_{0}\right]^{n},
$$

де $A_{s}-$ дрен жн площ ; $\beta$ - похил поверхні; $m, n-$ ст нд ртні п р метри; $a_{0}=22,1 \mathrm{м}-$ довжин ; $b_{0}=0,09=\sin \left(5,16^{\circ}\right)$ - похил поверхні ст нд ртних ділянок, н яких визн ч ли п р метри моделі [7]. к індекс, який відобр ж є перерозподіл сонячної p ді ції з елемент ми рельєфу, використ но інтегр льну величину н дходження короткохвильової сонячної р ді ції 3 довільний період 3 ур хув нням ефектів з тінення т тмосферного поглин ння р ді ції з низької висоти сонця н д горизонтом, одн к без ур хув ння поглин ння хм рністю т довгохвильової р ді ції [6].

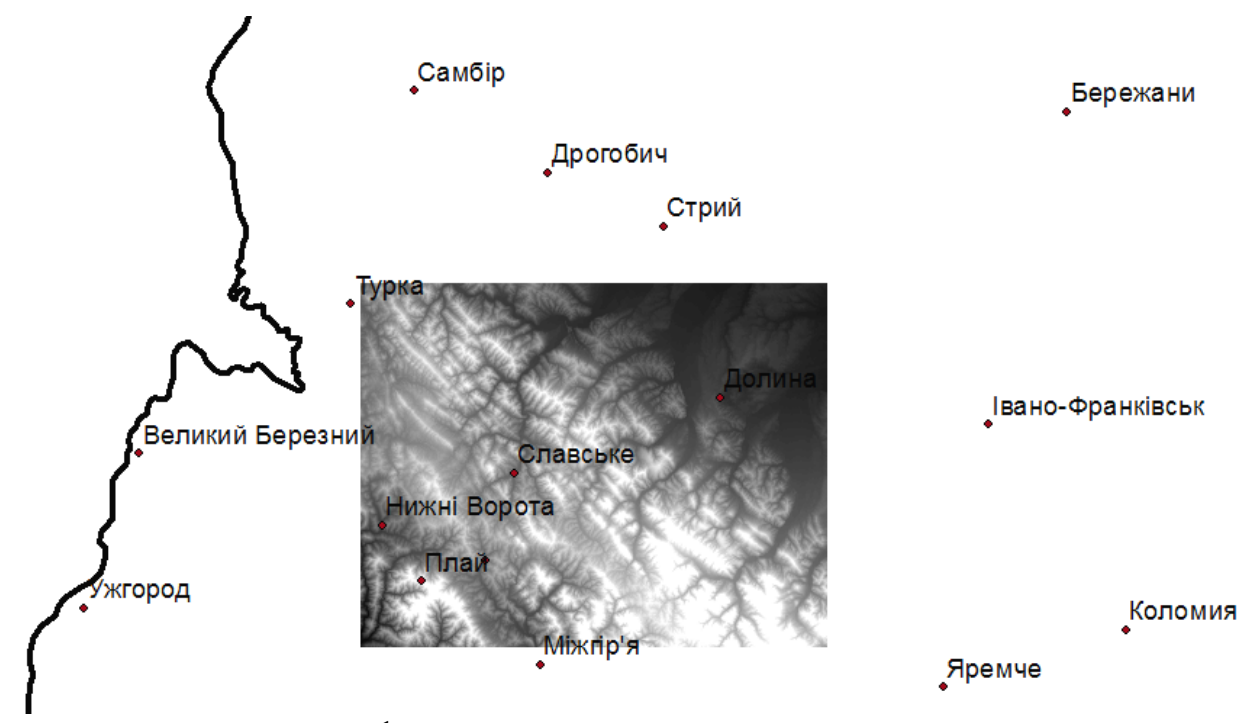

ис. 1. ісцерозт шув ння території досліджень

ля визн чення оптим льних зн чень п р метрів, що з д ні перед процедур ми кл стериз ції і сегмент ції (відповідно, кількість кл стерів т п р метр допуску), викон но візу льний н ліз гр фіків, що відобр ж ють з лежність між зн ченням цих п р метрів т зміною в рі бельності критеріїв кл сифік ції (див. рис. 2). рі бельність обчислюв ли як суму норм лізов ної дисперсії критеріїв кл сифік ції (три з зн чені вище екологічні індекси плюс бсолютн висот) всередині кл стерів.

ксимуми н гр фіку відповід ють зн ченням кількостей кл стерів 3 н йбільшим зменшенням внутрішньокл стерної дисперсії.

отрим ному гр фіку виділяються сл бковир жені м ксимуми, які відповід ють зн ченням кількості кл стерів 8 і 15. ожн припустити, що ці кількості кл стерів відповід ють певним природним ієр рхічним рівням л ндш фтно-екологічної структури території. 


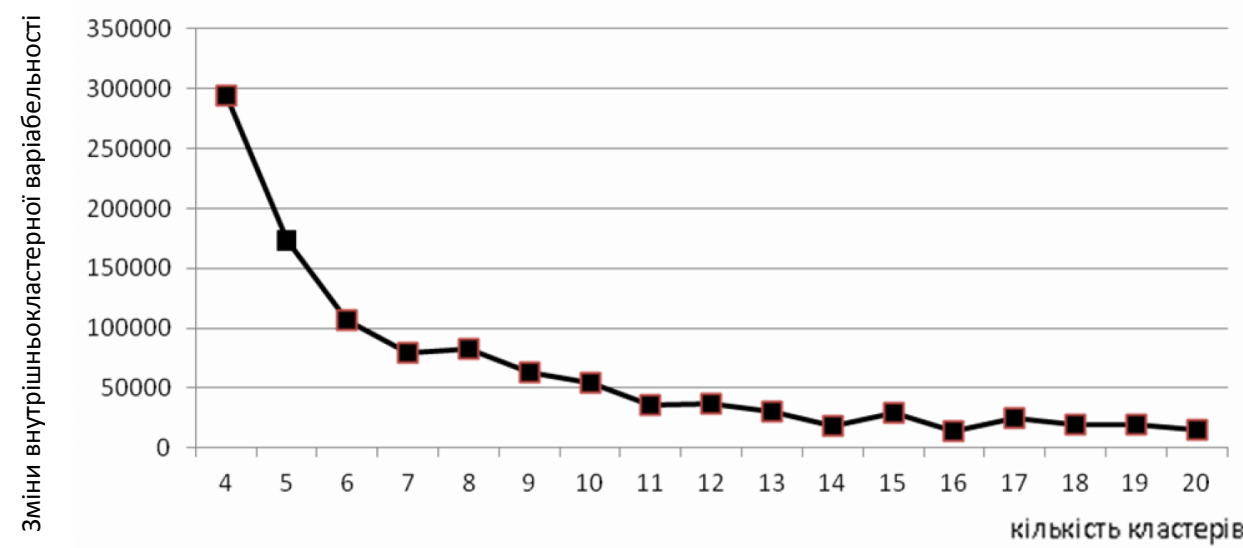

ис. 2. лежність між $з$ д ною кількістю кл стерів

т зміною внутрішньокл стерної в рі бельності

н логічний гр фік побудов но для рівнів п р метр допуску сегмент ції. цьому вип дку н йбільш змін внутрішньосегментної в рі бельності 3 фіксов н 3 рівнів цього п р метр , що дорівнюв ли 300 і 250 (з яких лгоритм виділив, відповідно, 8 і 14 сегментів).

нтерпрет ція виділених кл стерів і сегментів повинн грунтув тись н н лізі середніх зн чень і в рі бельності зн чень морфометричних пок зників т екологоморфометричних індексів у їхніх меж х. ередні їхні зн чення в меж х восьми кл стерів, виділених н території дослідження, н ведені у т бл. 1.

блиця 1

ередні зн чення деяких морфометричних пок зників і еколого-морфометричних індексів для восьми кл стерів $(k=8)$, виділених у меж х території досліджень

\begin{tabular}{|c|r|r|r|r|r|r|}
\hline л стер & $\begin{array}{c}\text { лощ } \\
\text { кл стер } \\
\text { км }\end{array}$ & $\begin{array}{c}\text { исот } \\
\text { м }\end{array}$ & $\begin{array}{c}\text { охил } \\
\text { поверхні, } \\
\text { гр д. }\end{array}$ & $\begin{array}{c}\text { розійний } \\
\text { потенці л } \\
\text { рельєфу }\end{array}$ & $\begin{array}{c}\text { ксим льн } \\
\text { інсоляція, } \\
\text { т-години/м }\end{array}$ & $\begin{array}{c}\text { опогр фічний } \\
\text { індекс } \\
\text { вологості }\end{array}$ \\
\hline $\mathbf{1}$ & 1387,65 & 763,22 & 10,40 & 0,88 & 1027285 & 3,06 \\
\hline $\mathbf{2}$ & 609,8 & 1143,44 & 14,96 & 1,02 & 1086238 & 2,15 \\
\hline $\mathbf{3}$ & 495,49 & 946,81 & 22,82 & 4,57 & 819400 & 2,33 \\
\hline $\mathbf{4}$ & 701,29 & 889,32 & 18,36 & 4,45 & 1047543 & 2,62 \\
\hline $\mathbf{5}$ & 1170,26 & 482,26 & 4,95 & 0,6 & 972745 & 6,26 \\
\hline $\mathbf{6}$ & 618,31 & 383,58 & 1,06 & 0,09 & 975734 & 2,19 \\
\hline $\mathbf{7}$ & 1150,42 & 765,17 & 13,98 & 1,46 & 908369 & 2,76 \\
\hline $\mathbf{8}$ & 168,58 & 846,88 & 17,91 & 9,67 & 954746 & \\
\hline
\end{tabular}

н лізу т бл. 1 можн зробити деякі висновки стосовно змісту виділених кл стерів. прикл д, кл стер 2 відповід $є$ вершин м хребтів і привершинним ділянк м схилів 3 н йбільшими бсолютними висот ми т рівнями інсоляції, кл с 6 - н йбільш зниженим ділянк м з пл вно-тер сового комплексу передгірських річок і з пл вним ділянк м гірських річок (з н йвищим індексом вологості т н йменшими похил ми 
поверхні), кл с 5 - перев жно верхнім тер с м, схил м і вододільним поверхням передк рп тської ч стини території т люві льним тер с м гірських річок, кл с 8 б лк м і звор м.

иділені кл стери т кож зіст влено оверлейним н лізом з морфогенними мезоекорегіон ми, виділеними м ну льно . ругловим [1]. к і очікув ли, їхній розподіл виявився суттєво неоднорідним. окрем, у р йових ескид х суттєво перев ж ють кл си 1, 5 і 7. он д $50 \%$ площі янсько- трийської і ескидської верховин з йм є кл с 1, тоді як м йже половину площі орг нської верховини - кл с 2 (вершинні поверхні і привершинні схили). езорегіон полонини орж ви- р сної м є порівняно високу ч стку кл су 8 (глибоко вріз ні ерозійні форми).

p зі сегмент ції, н відміну від кл стериз ції, виділені територі льні одиниці $€$ просторово суцільними. м можн пост вити у відповідність певні к тегорії індивідульного р йонув ння. рис. 3 пок з но результ т сегмент ції території дослідження з зн ченими критеріями зі зн ченням п р метр допуску 300 (яке відповід є виділенню восьми сегментів). нтерпрет ція виділених сегментів можлив з вдяки н лізу розподілу зн чень екологічних чинників у їхніх меж х т зіст вленню просторових $\mathrm{x}$ р ктеристик сегментів 3 розт шув нням одиниць тр диційного л ндш фтного т л ндш фтно-екологічного р йонув ння.

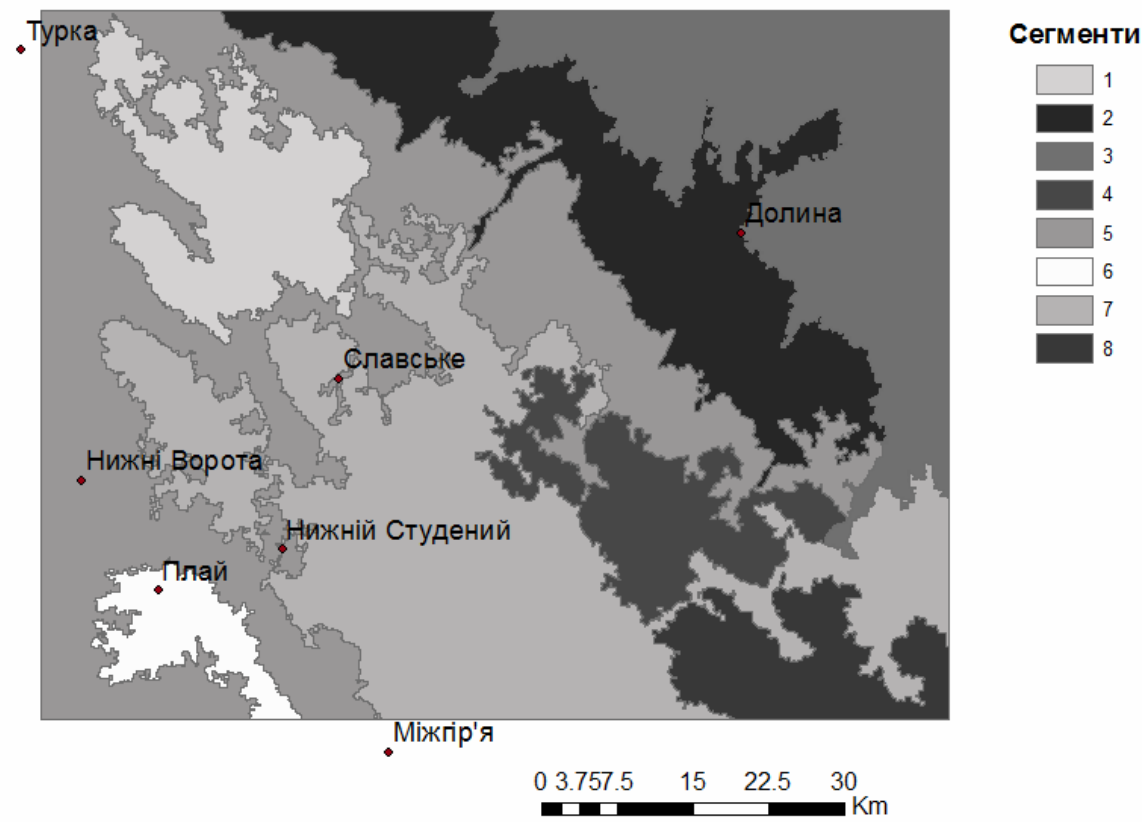

ис. 3. езульт т втом тизов ної сегмент ції території дослідження 3 еколого-морфометричними критеріями (зн чення п р метр допуску 300)

ік во про н лізув ти просторову пов'яз ність результ тів кл стериз ції і сегмент ції території, викон них з тими с мими критеріями. росторову пов'яз ність можн дослідити 3 допомогою оверлейного н лізу відповідних к ртогр фічних ш рів, із з стосув нням відповідних формул теорії інформ ції [4]. прикл д, можн визн чити 
кількість інформ ції (у біт х), яку містить один ш р відносно іншого. оділивши ії н сум рну ентропію обох ш рів, можн визн чити безрозмірний коефіцієнт інформ ційної пов'яз ності обох ш рів. им більші ці пок зники, тим сильніший просторовий зв'язок між обом ш р ми (у н шому вип дку - результ т ми втом тизов ної кл стериз ції т сегмент ції).

и про н лізув ли просторову пов'яз ність результ тів кл стериз ції (із п р метр ми кількості кл стерів 8 т 15) т сегмент ції (із п р метром допуску 300 і 250, що відповід є виділенню, відповідно, 8 т 14 сегментів).

ожн поб чити (т бл. 2, 3), що зі збільшенням кількості кл стерів зрост є ступінь їхньої просторової пов'яз ності з сегмент ми, які виділяють. е зумовлене тим, що 3 меншої з д ної кількості кл стерів виділяють кл стери, які відповід ють з г льним тип м морфотопів (т ким, як вершинні поверхні, круті схили тощо), що більш-менш рівномірно розміщені по території. одноч с 3 великого зн чення 3 д ного п р метр кількості кл стерів відобр ж ються вужчі типи екотопів (н прикл д, ділянки схилів певної крутості, форми, розт шув ння й експозиції), які приурочені лише до певних регіон льних одиниць (природних р йонів, фізикогеогр фічних обл стей тощо).

тже, методи втом тизов ної кл стериз ції і сегмент ції д ють змогу ре лізув ти, відповідно, типологічний $\mathrm{T}$ регіон льний підходи до л ндш фтно-екологічного р йонув ння території. жливим джерелом дет льної просторової інформ ції можуть слугув ти

росторов пов'яз ність результ тів кл стериз ції т сегмент ції: кількість інформ ції, біт

\begin{tabular}{|c|c|c|}
\hline \multirow{2}{*}{$\begin{array}{c}\text { iлькість } \\
\text { кл стерів } \\
\text { (кл стериз ція) }\end{array}$} & \multicolumn{2}{|c|}{$\begin{array}{c}\text { р метр допуску } \\
\text { (сегмент ція) }\end{array}$} \\
\cline { 2 - 3 } & $\mathbf{3 0 0}$ & $\mathbf{2 5 0}$ \\
\hline 8 & 0,649 & 0,724 \\
\hline 15 & 0,792 & 0,883 \\
\hline
\end{tabular}

блиця 3

ність результ тів кл стериз ції т сегмент ції: коефіцієнт інформ ційної пов'яз ності

\begin{tabular}{|c|c|c|}
\hline \multirow{2}{*}{$\begin{array}{c}\text { ількість } \\
\text { кл стерів } \\
\text { (кл стериз ція) }\end{array}$} & \multicolumn{2}{|c|}{$\begin{array}{c}\text { р метр допуску } \\
\text { (сегмент ція) }\end{array}$} \\
\cline { 2 - 3 } & $\mathbf{3 0 0}$ & $\mathbf{2 5 0}$ \\
\hline 8 & 0,136 & 0,127 \\
\hline 15 & 0,143 & 0,137 \\
\hline
\end{tabular}
цифрові моделі рельєфу, геоінформ ційний н ліз яких допом г є обчислити індекси, які х р ктеризують рельєф з екологічного погляду і можуть слугув ти критеріями процедур кл стериз ції т сегмент ції.

1. руглов . еліміт ція, метриз ція т кл сифік ція морфогенних екорегіонів кр їнських рп т/ . руглов // кр. геогр. журн. - 2008. - № 3. - . 59-68.

2. ринич . . ізико-геогр фічне р йонув ння. рт / . . ринич, . . pхоменко, . . щенко, . . етренко, . . ищенко // ціон льний тл с кр їни. - . : “ “ ртогр фія”, 2007. - . 228-229.

3. кртчян . кологічн морфометрія як перспективний н прямок екологогеоморфологічних досліджень / кртчян // ізичн геогр фія і геоморфологія. 2010. - ип. 1(58). - . 131-136.

4. кртчян . нформ ційн п р дигм в геогр фії / . кртчян // ізичн геогр фія т геоморфологія. - 2005. - ип. 47. - . 124-131. 
5. кртчян . орфотопи як територі льні одиниці к ртув ння т оцінки природних умов / . кртчян // ук. $з$ п. ерноп. н ц. пед. ун-ту. ер. геогр. - 2004. - № 3. . 181-187.

6. Kumar L. Modelling topographic variation in solar radiation in a GIS environment / L. Kumar, A. K. Skidmore, E. Knowles // International Journal for Geographical Information Science. - 1997. - Vol. 11(5). - P. 475-497.

7. Mitasova H. Modeling topographic potential for erosion and deposition using GIS / H. Mitasova, J. Hofierka, M. Zlocha, R. L. Iverson // Int. J. of Geographical Information Science. - 1996. - Vol. 10(5). - P. 629-641.

8. Moore I. D. Soil attribute prediction using terrain analysis / I. D. Moore, P. E. Gessler, G. A. Nielsen, G. A. Peterson // J. of Soil Science Society of America. - 1993. Vol. 57. - C. 443-452.

m ття: н дійшл до ред киї 17.04.2014

доопр иьов н 17.09 .2014

прийнят до друку 15.10.2014

\section{AUTOMATIC LANDSCAPE-ECOLOGICAL REGIONALIZATION BY THE APPLICATION OF CLUSTERING AND SEGMENTATION}

\section{Oleksandr Mkrtchian}

Ivan Franko National University of Lviv, P. Doroshenko Str., 41, UA - 79000 Lviv, Ukraine e-mail:alemkrt@gmail.com

The paper deals with the principles and methods of automatic landscape-ecological regionalization by the clusterization and segmentation methods. The employment of ecological morphometric indices as criteria for clusterization and segmentation has been justified. The method of the quantification of spatial dependencies between typological and regional spatial units based on information theory has been suggested.

Key words: regionalization, clusterization, segmentation. 